\title{
OPTIMIZATION OF REDUCTION PROCESS OF EGYPTIAN ILMENITE VIA METALLOTHERMIC REACTIONS
}

\author{
A.M. Daher ${ }^{1}$, N.A. Badawy ${ }^{2}$,Waleed.A.Mohrez ${ }^{1}$ Abb allhm.abbel-Hamid ${ }^{1}$, A.yossef ${ }^{2}$, A.Abd El \\ Pasir $^{1}$ \\ 1 Nuclear Materials Authority, Cairo, Egypt \\ 2Chemistry Department, Faculty of Science, Al-Azhar University (Girls), Nasr City, Cairo, Egypt
}

\begin{abstract}
It is important to develop technologies for the production of master alloys for industrial applications. Detailed research on reduction of titanium from Egyptian ilmenite by an aluminothermic process in a graphite Crucible was charged by the mixture of ilmenite, flux, aluminum was investigated. This paper study the effect of aluminum feed (10\% - 35\%), flux material (type, and amount), and temperature preheat from $50{ }^{\circ} \mathrm{C}$ to $400{ }^{\circ} \mathrm{C}$ and time of preheating from $0.5 \mathrm{hr}$. to $3 \mathrm{hrs}$. Then, the metallic samples formed by the reduction were analyzed using $X$-ray diffraction, scanning electron microscopy. The mixed fluxes were strongly and successfully reduced ilmenite to a high-purity master alloy with small amounts of detected impurities.
\end{abstract}

Key words: Aluminothermic, Egyptian ilmenite, flux, ferrotitanium, master alloy

\section{INTRODUCTION}

In the past decade, intensive investigations have led to a new direct route for the extraction of metals and alloys from their oxides by using molten salt electrolysis. Oxygen removal from solid oxides is the essence of this method. In that process, some promising techniques associated with metallothermic and electrochemical deoxidization routes such as the Fray-FarthingChen (FFC) Cambridge process [1], electrolysis-assisted calciothermic reduction process [2], the Electronically Mediated Reaction (EMR) process [3] the Preform Reduction (PRP) process [4], and the Solid Oxide-Oxygen-Ion Conducting Membrane (SOM) process [5] have been introduced for direct reduction of oxides[6].

On the other hand, recently the authors investigated the sintering behaviour to $1200{ }^{\circ} \mathrm{C}$ of blended elemental (BE) Ti-2.5Fe. It was found that when relatively coarse elemental $\mathrm{Fe}$ powder was used, large rounded pores of roughly the size of the original Fe particles resulted. This was shown to be caused by melting at the first eutectic temperature of 1085 ${ }^{\circ} \mathrm{C}$, followed by rapid diffusional solidification. An associated exothermic reaction between the liquid phase and surrounding iron also caused some swelling and expansion in the powder compact. Adding a hold to the sintering profile below the eutectic temperature suppressed any liquid formation by allowing sufficient interdiffusion of the $\mathrm{Ti}$ and $\mathrm{Fe}$ constituents. [7]

Specially the ultrafine eutectic Ti-Fe alloys, containing FeTi in the $\mathrm{B} 2(\mathrm{CsCl})$ phase and a b$\mathrm{Ti}(\mathrm{Fe})$ solid solution, have been shown to simultaneously possess both high strength and good ductility in recent experiments [8-11]. Various titanium metallurgical processes have been reviewed and compared for titanium dioxide and titanium metal, mainly focusing on the future development of hydrometallurgical processes. It is recognized that ilmenite is becoming increasingly important due to the rapid depletion of natural rutile. Many processes are commercially used or proposed to upgrade ilmenite to synthetic rutile. Most of these processes involve a combination of pyrometallurgy and hydrometallurgy and are generally expensive. [12]

Ti-based alloys represent a class of materials with a great potential in automotive, aerospace and biomechanical applications because of their low density $\left(w 4.5 \mathrm{~kg} / \mathrm{m}^{3}\right)$, sufficient corrosion resistance, high strength (w1000 MPa), and good ductility with a plastic elongation to failure of $10 \mathrm{e} 15 \%$ [14-16].

The enhancement of ilmenite reduction has been extensively studied, which include the pre-oxidation process, addition of an alkali metal salt, mechanical activation, and 
microwave reduction [13-17]. These strengthening methods can accelerate the reduction rate of carbothermic reduction in several ways. However, these methods have several disadvantages: the extra investment for the pre- oxidation process and mechanical activation, the negative effects of the refractory lining for the addition of alkali metal salt, and the necessitation of high-level equipment for microwave reduction.[18]

Due to the increased demand of master alloy, where it used as alloying method to dissolve the required element inside the main matrix alloy, such demand makes the research and development to proceed into the production of master alloy is indispensable. Ferro titanium is one of the most wide range applicable alloy to be used as reducing agent in steel making as well as alloying method to dissolve titanium in the matrix of variant classes of stainless steel i.e. stabilized grades. Titanium and titanium alloys have many desirable properties such as light mass, high strength, biocompatibility, good conductivity and corrosion resistance. They are attractive materials in various fields such as metallurgy, navigation, aerospace, chemical industries, and biomedicine. However, their widespread application has been retarded due to the costly and environmentally unfriendly production and processing [19] they have high strength to weight ratios which make them ideally suited for automotive applications [20-22]. In addition, as a light weight replacement for stainless steel, $\mathrm{Ti}$ alloys have the potential to reduce greenhouse gas emissions during the operation of a vehicle [23]. A primary challenge to the widespread adoption of Ti alloys in the automotive industry is its relatively high cost $[20,21]$.

In this context,the production of $\mathrm{Fe}-\mathrm{Ti}$ master alloys using more economical processes than the traditional carbothermic process was investigated using electrochemical reduction processes, as these require fewer processing steps, have low labor requirements, can reduce combinations of different metal oxides to form alloys, and are environmentally friendly [24].

\section{2- Materials and Experimental Methods}

\section{Ilmenite sample was obtained from Rossetta Egyptian black sand}

act as a natural source of $\mathrm{TiO}_{2}$ and $\mathrm{Fe}_{2} \mathrm{O}_{3}$ as seen in a table (1), aluminum (metal) powder, $\mathrm{CaCO}_{3}$ powder, feldspar, $\mathrm{Fe}_{2} \mathrm{O}_{3}$ and magnesium strip and graphite crucible as reactor and XRD, Axios advanced, Sequential WD_XRF Spectrometer, PANalytical 200used for analysis the product alloy and slag. Firstly, the thermodynamic calculations applying computer program HSC chemistry 5.1., was carried out using the physical chemistry parameters; enthalpy and Gibbs free energy to judge on the effectiveness of each deoxidizer. Then, sets of experiments were done as seen in Fig.(1)and study the factors affecting the yield and purity of the produced master alloy.

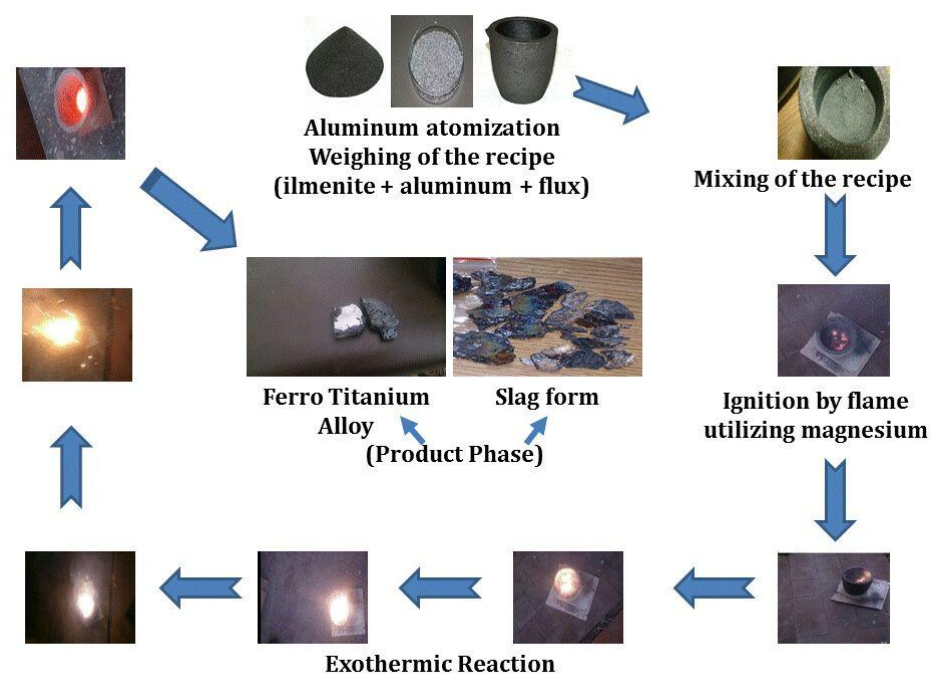

Fig. (1) Flow sheet illustrating the sequence of the process. 


\section{3-RESULTS AND DISCUSSION}

\section{3-1- Chemical Characterization of Egyptian Ilmenite Sample}

Ilmenite was analyzed by both of XRF and XRD that we can see from the chemical analysis of ilmenite (Table 1), the concentration of $\mathrm{TiO}_{2}$ reached about $39.7 \%$ which meaning its low grade ilmenite but from the XRD pattern (Fig. 2), we can notice that ilmenite has not the pseudo-mineral Leucoxene which is more harder than ilmenite in the reduction process.

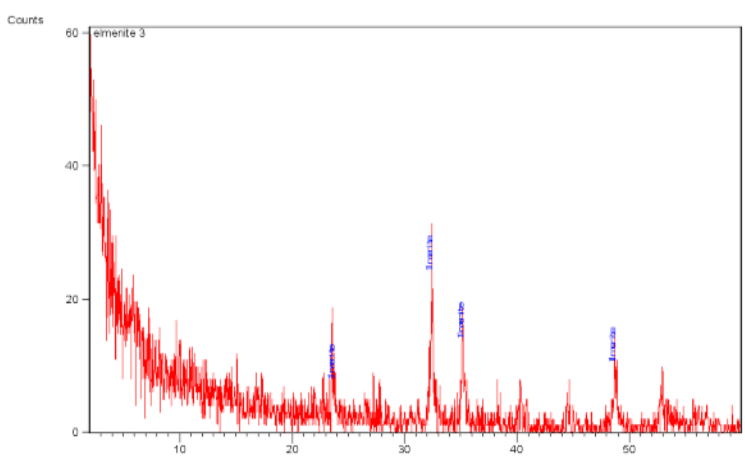

Fig. (2): XRD pattern of ilmenite sample

Table (1): Chemical composition of ilmenite

\begin{tabular}{|c|c|}
\hline Component Formula & Concentration (wt \%) \\
\hline $\mathbf{N a}_{\mathbf{2}} \mathbf{O}$ & 0.574 \\
\hline $\mathbf{M g O}$ & 0.738 \\
\hline $\mathbf{A l}_{2} \mathbf{O}_{\mathbf{3}}$ & 1.094 \\
\hline $\mathbf{S i O}_{\mathbf{2}}$ & 3.385 \\
\hline $\mathbf{P}_{\mathbf{2}} \mathbf{O}_{\mathbf{5}}$ & 0.060 \\
\hline $\mathbf{S O}_{\mathbf{4}}$ & 0.085 \\
\hline $\mathbf{K}_{\mathbf{2}} \mathbf{O}$ & 0.086 \\
\hline $\mathbf{C a O} \mathbf{O}$ & 0.851 \\
\hline $\mathbf{T i O}_{\mathbf{2}}$ & 39.721 \\
\hline $\mathbf{C r}_{\mathbf{2}} \mathbf{O}_{\mathbf{3}}$ & 0.333 \\
\hline $\mathbf{M n O}$ & 1.480 \\
\hline $\mathbf{F e}_{2} \mathbf{O}_{\mathbf{3}}$ & 51.079 \\
\hline $\mathbf{Z n O}$ & 0.050 \\
\hline $\mathbf{Y}_{\mathbf{2}} \mathbf{O}_{\mathbf{3}}$ & 0.007 \\
\hline $\mathbf{Z r O}_{\mathbf{2}}$ & 0.147 \\
\hline $\mathbf{N b}_{\mathbf{2}} \mathbf{O}_{\mathbf{5}}$ & 0.050 \\
\hline $\mathbf{C l}$ & 0.260 \\
\hline
\end{tabular}

\section{3-2- Thermodynamic Calculation for Deoxidizer Selection}

The thermodynamic calculations reflect clearly the road map of such aspect, we selected three oxidizers; calcium, silicon, aluminum, and make the thermodynamic calculations by HSC modeling platform, using the physical chemistry parameters; enthalpy and Gibbs free energy to judge on the effectiveness of each deoxidizer, the output data (Fig. 3a,b and 4a,b), showed that when using calcium and aluminum they have more negativity of each enthalpy and Gibbs free energy than silicon in case of reduction titanium dioxide this behavior of calcium and silicon was the same with iron oxide, where both calcium and silicon; almost showed the same behavior for reduction of iron oxide, and aluminum showed more negativity for enthalpy and Gibbs free energy, although calcium has more reduction potentiality than aluminum for titanium dioxide, but this difference not considerable enough to make calcium more likely than aluminum in reduction process, due to financial aspects and viability of calcium.

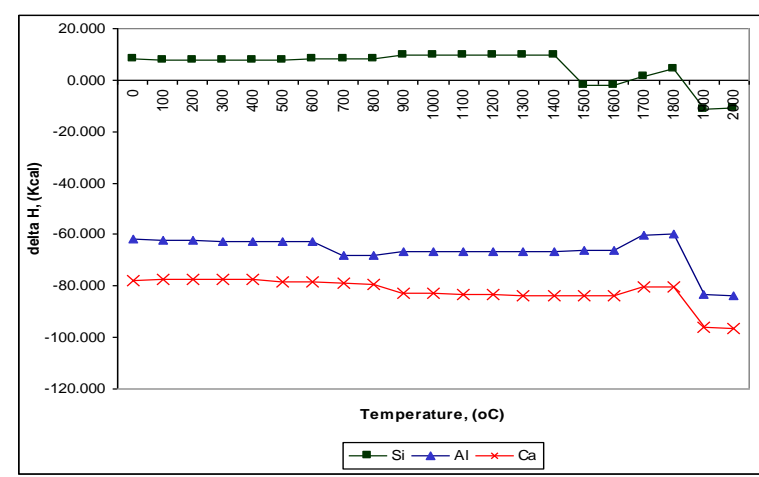

Fig. (3): (a), the correlation between delta $H$, and temperature of calcium, silicon, aluminum for reduction of Titanium dioxide

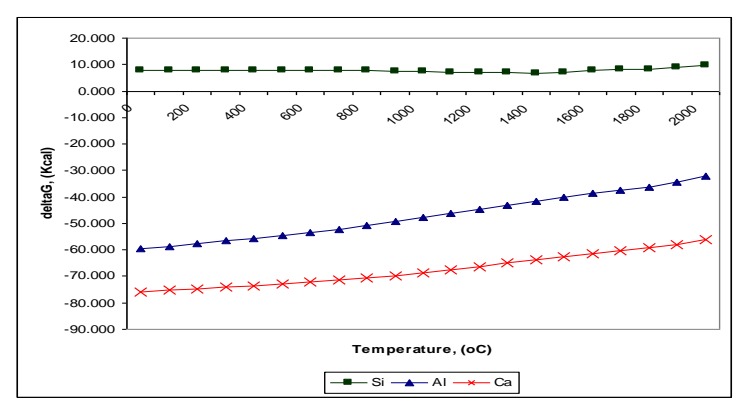

Fig. (3): (b), the correlation between delta G, and temperature of calcium, silicon, aluminum for reduction of Titanium dioxide 


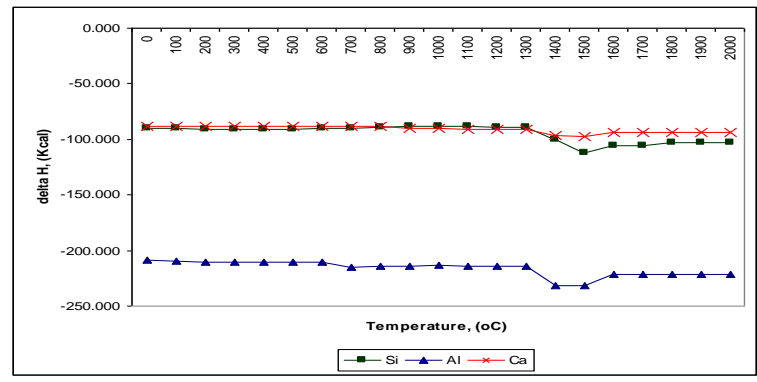

Fig. (4): (a), the correlation between delta $\mathrm{H}$ and temperature of calcium, silicon, aluminum for reduction of iron oxide

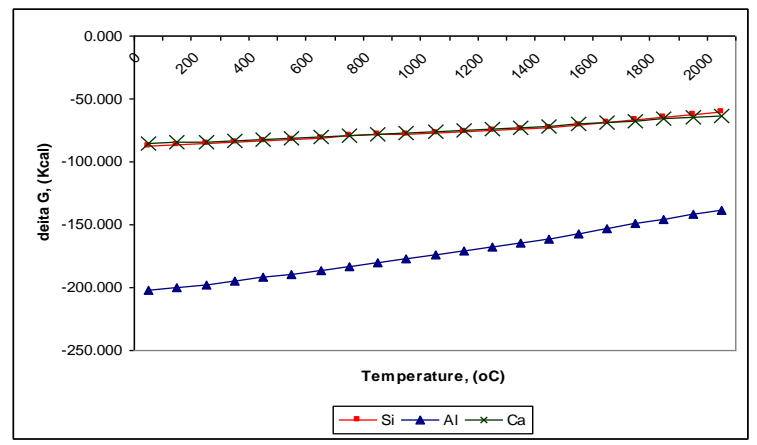

Fig. (4): (b), the correlation between delta $G$ and temperature of calcium, silicon, aluminum for reduction of iron oxide

\section{3-3- Effect of Aluminum Ratio upon Titanium Yield in the Master Alloy}

To study the effect of $\mathrm{Al}$ to the mass recipe (ilmenite + flux) ratio upon the yield of titanium in the alloy sets of experiments are established as the following: $10 \%, 15 \%, 20 \%$, $25 \%, 30 \%, 35 \%$, and $40 \%$. It can be seen from the obtained results (Fig. 5), that the titanium yield in the produced master alloy (The formed $\mathrm{Fe}_{2} \mathrm{Ti}$ weight), function is linear proportionally with $\mathrm{Al}$ concentration until $35 \%$ it reaches about $52 \%$ then begins to decrease. Also, it was noticed that these results are matched with the results obtained from the theoretical thermodynamic pre-calculation studies. While, the recovery is empirical parameter was calculated by the known feed weight and it's titanium content and the output weight of the ferrotitanium alloy produced and its titanium content, where the recovery $\% \mathrm{R}=\mathrm{Cc} / \mathrm{Ff}$ and 35 $\%$ is the optimum value of aluminum ratio.

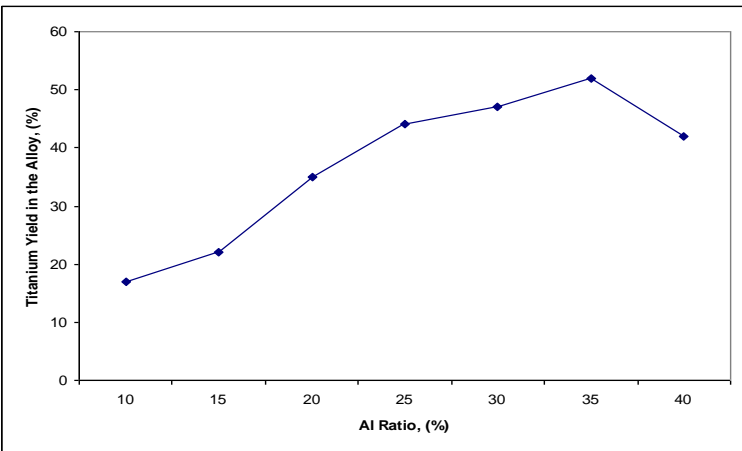

Fig. (5): Effect of aluminum ratio upon titanium yield in the master alloy

\section{3-4- Effect of Flux Materials upon Titanium Yield in the Master Alloy}

To study the effect of flux to recipe mass (ilmenite $+\mathrm{Al}$ ) ratio upon titanium yield in the master alloy the following experiments were established: different types of flux were used as feldspar, calcium carbonate with different ratios to the recipe as $2 \%, 4 \%, 6 \%, 8 \%, 10 \%$, and $12 \%$. The obtained results (Fig. 6) show that calcium carbonate is better than feldspar and the titanium yield in the alloy in case of calcium carbonate increases with increasing of flux ratio till $10 \%$ the yield reaches about $58 \%$. Also, another experiments were established by mixing the two (calcium carbonate and feldspar), fluxes with different ratios to each other with keeping the flux ratio to the recipe constant at 10\%. The obtained results (Fig. 7), show that the titanium yield in the alloy increases with mixing of the two fluxes till the ratio $8 / 2 \mathrm{CaCO}_{3} /$ feldspar it reaches about $63 \%$ then the yield decreases with increasing of feldspar ratio as a flux.The flux play very important roles in alloy fabrication that it decreases the melting point from $2000{ }^{\circ} \mathrm{C}$ to $1600{ }^{\circ} \mathrm{C}$ and lowers the basicity of the slag [25], also, the flux herein prevents the formation of oxides of the alloy metals when they are in contact with air [26].We can see also that, $10 \%$ of the flux ratio to the recipe and $8 / 2 \mathrm{CaCO}_{3} /$ feldspar ratio is the optimum ratio.

\section{3-5- Effect of Ferrous Oxide upon Titanium Yield in the Master Alloy}

When using different ratios of "FeO" weight to the recipe: $5,10,15,20,25,30$ and $35 \%$. The obtained results (Fig. 8), show that, 


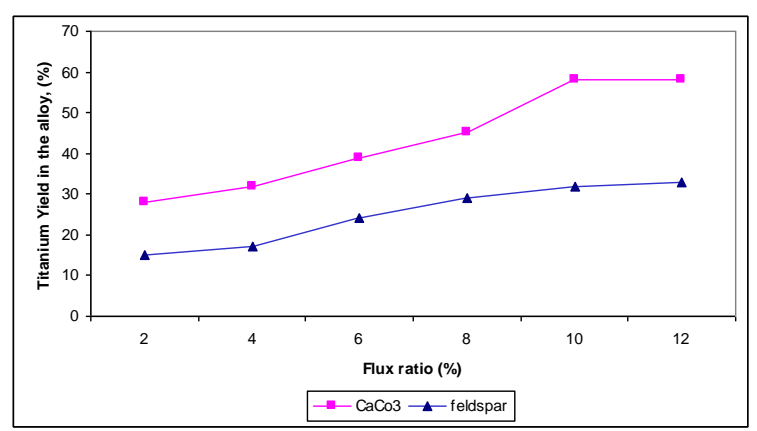

Fig. (6): Effect of flux ratio upon titanium yield in the master alloy

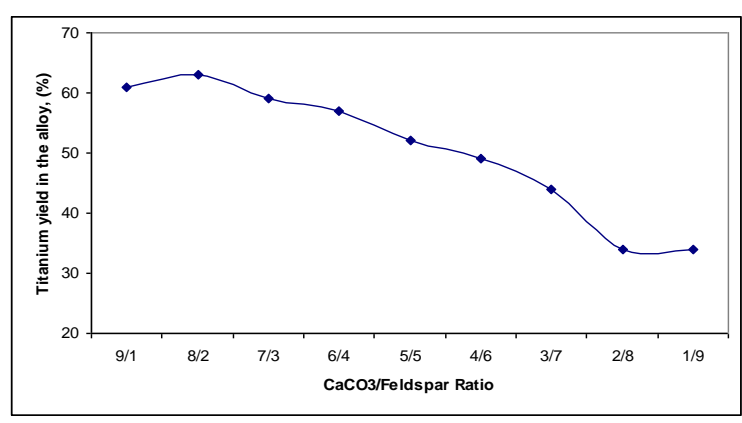

Fig. (7): Effect of $\mathrm{CaCO}_{3} /$ feldspar ratio as flux upon titanium yield in the master alloy

the titanium yield in the produced master alloy increases with the increasing of ferrous oxide ratio and $30 \%$ is the optimum ratio that the yield reaches about $63 \%$. Also, we can see that these results are matched with the results obtained from the theoretical thermodynamic pre-calculation studies which proved that the formed phase is $\mathrm{Fe}_{2} \mathrm{Ti}$ and the correlation between $\mathrm{FeO}$ percentage and the formed $\mathrm{Fe}_{2} \mathrm{Ti}$ weight is linear proportionally, and it was noticed that the phase of FeTi was detected as intermediate unstable compound, but it is not recovered product.

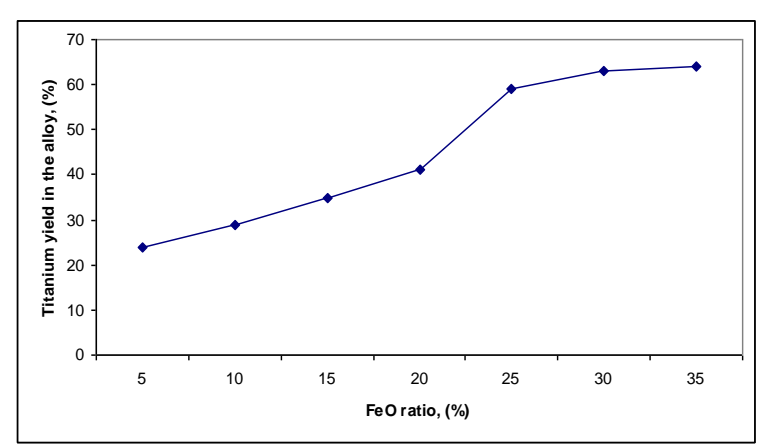

Fig. (8): Effect of ferrous oxide ratio as flux upon titanium yield in the master alloy

\section{3-6- Effect of Preheat Temperature upon Titanium Yield in the Master Alloy}

At this stage the recipe was preheated at convection oven, to heat up the sample from ambient temperature to different elevated temperatures, at $4 \mathrm{~h}$ holding time, where the recipe was heated up to temperatures $150{ }^{\circ} \mathrm{C}$, $200{ }^{\circ} \mathrm{C}, 250{ }^{\circ} \mathrm{C}, 300{ }^{\circ} \mathrm{C}, 350{ }^{\circ} \mathrm{C}, 400{ }^{\circ} \mathrm{C}$, because the reaction did not proceeds at room temperature and also at $50{ }^{\circ} \mathrm{C}$, after the pick up the sample from the convection oven the recipe was ignited by spark flam, utilizing magnesium tape, where magnesium at this stage playing only the role of trigger to initiate the exothermic reaction of the internal component of the recipe. Fig (9) Shows; the ignition and proceeding of the reaction and the obtained results show that the increase of preheat temperature till $400{ }^{\circ} \mathrm{C}$ are more effective in titanium yield in the alloy which reaches $63 \%$ due to increase the internal heat energy saved in the mixed constitutions which gives energy required to initiate the aluminothermic reaction process.

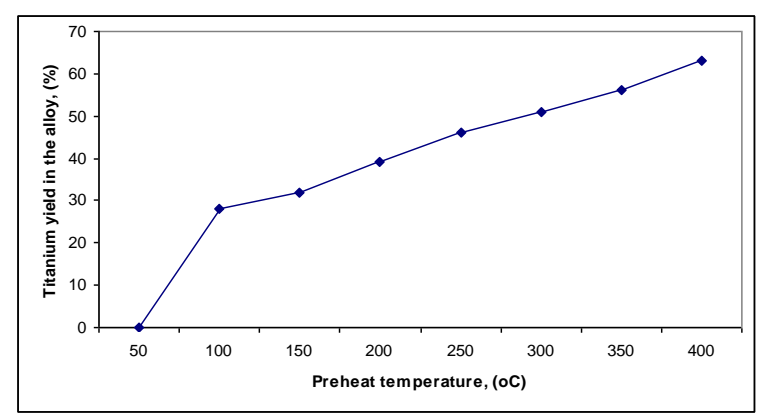

Fig. (9): Effect of preheat temperature upon titanium yield in the master alloy

\section{3-7- Effect of Preheat Time upon Titanium Yield in the Master Alloy}

To study the effect of preheat holding time upon titanium yield in the alloy, sets of experiments were conducted as follows: $400{ }^{\circ} \mathrm{C}$ and varied holding time; ranging from $0.5,1$, $1.5,2,2.5,3$, and 3.5 hours for each elevated. The obtained results (Fig. 10), show that the prolongation of preheat time to three hours and preheat temperature $400{ }^{\circ} \mathrm{C}$ are more effective in titanium yield in the alloy that the titanium 
yield in the alloy reaches $64 \%$ and be constant after that.

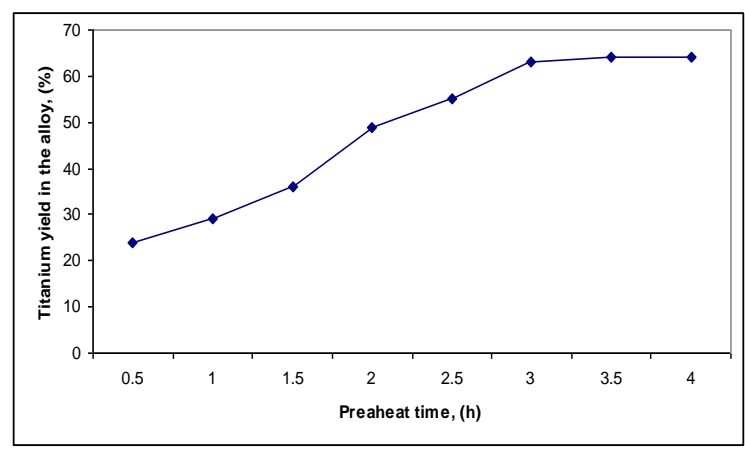

Fig. (10): Effect of preheat time upon titanium yield in the master alloy

\section{3-8- Properties of the Produced Ferrotitanium Master Alloy}

The Physical properties of the produced ferrotitanium alloy were summarized in the following table.

Table (2): Physical properties of the produced ferrotitanium alloy

\begin{tabular}{|l|c|}
\hline Physical state & Solid \\
\hline Colour & Metallic gray \\
\hline Odour & Odourless \\
\hline Melting point & $975^{\circ} \mathrm{C}-1525^{\circ} \mathrm{C}$ \\
\hline Boiling point & $>3000^{\circ} \mathrm{C}$ \\
\hline Specific gravity & $5.6-6.8 \mathrm{~g} / \mathrm{cm}^{3}$ \\
\hline
\end{tabular}

A

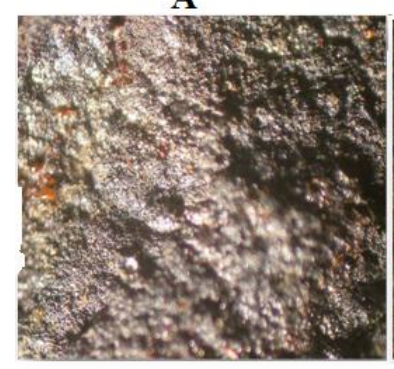

B

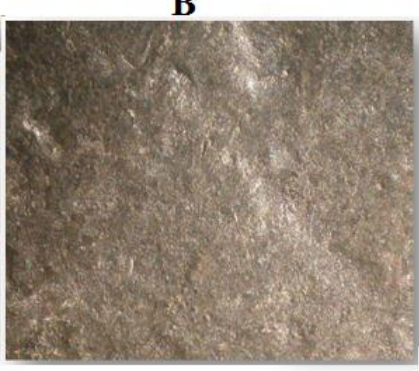

Fig (11): Produced ferrotitanium alloy as received (A) and after gauging and polishing (B)

After receiving the product of Ferro titanium alloy it was fully covered with protrusions and hard scales, due to the hindered mobility between slag and metallic phase, where such protrusions intermetallic phases is interphase layer consisting of mixture of traces of titanium and iron and balanced with alumina fig (11) A, so it was needed to gauge this layer by mechanical gauging followed by polishing to revived the polished face.

\section{CONCLUSION}

This study achieved promising results that using low grade ilmenite applying the optimum conditions $35 \%$ aluminum powder, flux mixture of calcium carbonate $8 \%$ and feldspar $2 \%$ and heating to $400^{\circ} \mathrm{C}$ for 3 hours. An alloy of ferrotitanium master alloy was fabricated with $63 \%$ titanium yield and recovery $96 \%$ of titanium from Egyptian ilmenite.

\section{REFERENCES}

1- G.Z. Chen, D.J. Fray, T.W. Farthing, Nature 407 (2000) 361

2- R.O. Suzuki, S. Inoue, Metallurgical and Materials Transactions B 34 (2003) 277

3- $\mathrm{T}$ H Okabe, I Park, K T Jacob, YWaseda, Journal of Alloys and Compounds 288 (1999) 200

4- T H Okabe, TOda, YMitsuda, Journal of Alloys and Compounds 364 (2004) 156

5- X. Zou, X. Lu, C. Li, Z. Zhou, Electrochimica Acta 55 (2010) 5173

6- Z. Zhou et al., "Electrolytic synthesis of ferrotitanium powders from ilmenite in $\mathrm{CaCl} 2$ $\mathrm{NaCl}$ melts at a lower temperature of $700{ }^{\circ} \mathrm{C}$," J. Alloys Compd., vol. 726, pp. 1124-1131, 2017

7- J. O'Flynn and S. F. Corbin, "The influence of Fe-40Ti intermetallic master alloy additions on the sintering behaviour of Ti-2.5Fe," J. Alloys Compd., vol. 716, pp. 184-196, 2017

8- J Das, KB Kim, F Baier, W Löser, J Eckert. Appl Phys Lett 2005;87:161907

9- J Das, K.B. Kim, F Baier, W. Löser, A Gebert, J. Eckert, J. Alloys Comp 2007;434e 435:28e31

10- A Schlieter, U Kühn, J Eckert, W Löser, T Gemming, M Friák, et al. In- termetallics 2011;19:327e35 [Personal communication]

11- L. F. Zhu et al., "Ab initio based study of finitetemperature structural, elastic and thermodynamic properties of FeTi," 
Intermetallics, vol. 45, pp. 11-17, 2014

12- Z.Wensheng, Z.Zhaowu and C. Chu Yong, A literature review of titanium metallurgical processes, Hydrometallurgy 108 (2011) 177188.

13- G. Chen, L. Li, C. Tao, J. Alloy Comp. 657 (2016) 515-518

14- G. Chen, Z. Song, J. Chen, J. Alloy Comp. 577 (2013) 610-614

15- K. Miura, K. Miyabayashi, M. Kawanari, ISIJ Int. 51 (2011) 1234-1239

16- J. Ru, Y. Hua, C. Xu, J. Alloy Comp. 583 (2014) 121-127

17- G. Chen, J. Chen, J. Peng, Powder Technology. 286 (2015) 218-222

18- X. Liao, J. Peng, L. Zhang, T. Hu, and J. Li, "Enhanced carbothermic reduction of ilmenite placer by additional ferrosilicon," J. Alloys Compd., vol. 708, pp. 1110-1116, 2017

19- A. IBRAHIM, R S. LIMA, C C BERNDT, B R. MARPLE, Fatigue and mechanical properties of nanostructured and conventional titania (TiO2) thermal spray coatings [J]. Surface \& Coatings Technology, 2007, 201: 7589-7596

20- F.H.S. Froes, H. Friedrich, J. Kiese, D. Bergoint, Titanium in the family automobile: The cost challenge, JOM. (2004) 40-44

21 - F.H.S. Froes, M.N. Gungor, M.A. Imam, Costaffordable titanium: The component fabrication perspective, JOM. (2007) 28-31

22- P.G. Esteban, L. Bolzoni, E.M. Ruiz-Navas, E. Gordo, PM processing and characterisation of Ti-7Fe low cost titanium alloys, Powder Metall. 54 (2011) 242-252

23- T.E. Norgate, G. Wellwood, The potential applications for titanium metal powder and their life cycle impacts, JOM. 58 (2006) 58-63

24- Minkler, W.W., Baroch, E.F., 1981. The production of titanium, zirconium and hafnium. In: Tien, J.K., Elliott, J.F. (Eds.), Metallurgical Treatises. AIME, pp. 171-189

25- M. Pourabdoli, S. Raygan, H. Abdizadeh and K. Hanaei. A New Process For The Production Of Ferrotitanium from Titania Slag. Canadian Metallurgical Quarterly, 46 (1), (2007): 17-24
26- M. N. ErvinaEfzan, W. L. Ng, Mohd Mustafa Al Bakri Abdullah. Effect of fluxes on 60Sn40Bi solder alloy on copper substrate. International Conference on Innovative Research. Series: Materials Science and Engineering 133 (2016).

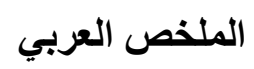

يعد انتاج السبائك من اهم الصناعات و التكنولوجيا الحديثة عديدة التطبيقات فى الصناعة. فى هذا البحث يتم اختز ال التيتـانيوم الموجـود فــى الاليمينيــت باســتخدام عمليـات الالو مينوثيرمك فى بوتقة من الجر افيت عن طريق خلط الاليمنيــت و المــادة المســاعدة و الالومنيـوم تــم اسـتخدام

الاومنيوم بنسب من • (\% ـ ه\% \% مادة مساعدة تم تغير نو عها وكميتها وتم التسخين المبدئي من ه, • ـ ب سـاعات ـ تم تحليل المو اد المختزلة الناتجة باسـتخدام اثـعة اكس و الميكروسـكزب الالكترونـى وتـم اثبـات و انتـاج سـبيكة خالية من الثوائب 